\title{
Solid Pseudopapillary Neoplasm of the Pancreas: Report of a Rare Case and Review of the Literature
}

\section{Pankreasın Solid Psödopapiller Neoplazmı: Nadir Bir Olgu Sunumu ve Literatürün Gözden Geçirilmesi}

\author{
Arzu Neşe YENER ${ }^{1}$, Manuk MANUKYAN ${ }^{2}$, Ahmet Midi' ${ }^{1}$, Rahmi ÇUBUK ${ }^{3}$ \\ Department of ${ }^{1}$ Pathology, ${ }^{2}$ General Surgery and ${ }^{3}$ Radiology, Maltepe University, Faculty of Medicine, ISTANBUL, TURKEY
}

\begin{abstract}
Solid pseudopapillary neoplasm, a rare primary neoplasm of the pancreas that typically affects young women, is a relatively indolent entity with favorable prognosis. We here report a 20 -year-old young girl with solid pseudopapillary neoplasm who presented with mild dull abdominal discomfort without any significant laboratory findings. On MRI, a heterogenous mass was found at the distal pancreas. The patient underwent en-block distal pancreatectomy with splenectomy with the presumptive diagnosis of cystic neoplasm of the pancreas. The tumor was well-circumscribed, encapsulated, $5.5 \mathrm{~cm}$ in the greatest dimension and showed typical papillary and pseudopapillary structures. Capsular invasion was seen on focal areas. The patient was not given any adjuvant therapy and shows no sign of disease after six months follow-up. It is important to differentiate this tumor from other pancreatic neoplasms because this neoplasm is amenable to cure after complete surgical resection even in cases with capsular invasion, unlike malignant tumors of the pancreas.
\end{abstract}

Key Words: Pancreatic neoplasm, Cystic, Papillary
ÖZ

Solid psödopapiller neoplazm, genç kadınlarda görülen ve iyi prognoza sahip, pankreasın nadir görülen bir tümörüdür. Bu sunumda, hafif karın ağrısı dışında tüm klinik ve laboratuvar bulguları normal olan, solid psödopapiller neoplazm tespit ettiğimiz 20 yaşındaki genç kadın hastayı sunmayı amaçladık. MR görüntülemesinde, distal pankreas yerleşimli $5,5 \mathrm{~cm}$ çapta kitle nedeniyle, pankreatik kistik neoplazi ön tanısıyla distal pankreatektomi ve splenektomi yapılan hastanın tümörünün mikrokopisinde tipik papiller ve psödopapiller yapılar vardı. Kapsül invazyonu fokal alanlarda bulunmakta idi. Hastaya ek tedavi verilmedi ve 6 . ay klinik izleminde metastaz ya da rekürrens bulgusu saptanmadı. Olgudaki gibi histopatolojik olarak kapsül invazyonu bulgusu izlense bile (solid psödopapiller) komplet cerrahi rezeksiyon yeterli olduğu ve klinik olarak benign davranış gösterdiğinden, pankreasın malign tümörlerinden ayırt etmek önemlidir.

Anahtar Sözcükler: Pankreatik tümörler, Kistik, Papiller

\section{INTRODUCTION}

Solid pseudopapillary neoplasm (SPN) of the pancreas almost exclusively affects young women and is a rare primary neoplasm (1-4). Although symptoms of SPNs are usually nonspecific and the preoperative diagnosis is often inaccurate, it has distinct pathologic features. Its importance comes from the fact that it may be misdiagnosed as a malignant tumor of the pancreas (1). In this study, we aimed to present the case of a 20 -year-old young girl with an SPN located in the distal part of the pancreas and briefly review the literature on this rare entity.

\section{CASE REPORT}

A 20-year-old young girl presented with history of mild, dull left sided-abdominal pain for the last two months. Laboratory examinations were unremarkable.

(Turk Patoloji Derg 2014, 30:228-232)

Received : 10.01.2011 Accepted : 04.08.2011
Computerized tomography and magnetic resonance imaging revealed a well-circumscribed, partly cystic and partly solid mass measuring $57 \times 48 \mathrm{~mm}$ in the tail of the pancreas (Figure 1A,B). The patient was operated on with the presumptive diagnosis of SPN or cystadenoma/ cystadenocarcinoma of the pancreas. Distal pancreatectomy with splenectomy was performed. There was no evidence of ascites or intraabdominal metastasis during surgery. Frozen section of a regional lymph node revealed no metastasis but reactive changes. The patient had an unremarkable postoperative course and was discharged 5 days after the operation.

On gross examination, there was a well-circumscribed and totally encapsulated mass measuring $55 \times 50 \times 45 \mathrm{~mm}$ located in the tail of the pancreas. On the cut surface, it was

Correspondence: Arzu Neşe YENER

Maltepe Üniversitesi, Tıp Fakültesi, Patoloji Anabilim Dalı, ISTANBUL, TURKEY

E-mail: nese.yener@yahoo.com Phone: +90 5053898454 
heterogenous and predominantly a cystic tumor. Focal solid areas were also present (Figure 2). The cystic parts were mainly filled with dark brown hemorrhagic debris. Normal pancreatic tissue was identified at the periphery. The spleen weighed $150 \mathrm{gm}$ and was in normal limits.

On microscopic examination, we observed a tumor mainly composed of cystic cavities lined by friable tissue and cholesterol clefts (Figure 3A). The solid parts grossly described were showing diffuse growth pattern with minimal supporting fibrovascular stroma. They were composed of papillary, pseudopapillary and microcystic structures with dyscohesive neoplastic cells (Figure 3B). The neoplastic cells in these areas had polygonal, uniform, centrally located grooved nuclei and vacuolated or eosinophilic large cytoplasm (Figure 3C). There were rare mitotic figures in solid areas. No atypical cells were found. The tumor was separated from the normal pancreatic tissue with a thick fibrous capsule in which there was infiltration of the tumor cells in some areas (Figure 3D). Surgical margins were free of tumor. Immunohistochemistry evaluation was performed. The tumor cells showed strong cytoplasmic positivity for vimentin (Figure 4A) and both nuclear and cytoplasmic positivity for $\beta$ catenin (Figure $4 \mathrm{~B})$. Weak or moderate staining for $\mathrm{p} 53$, pancytokeratin (PanCK), cyclinD1, CD10, synaptophysin, estrogen (ER) and progesterone receptors (PR) were observed. No immunostaining was seen for chromogranine A, CD34, CD117, cytokeratin 7 (CK7) and cytokeratin 20 (CK20). The proliferative index assessed by Ki-67 immunoreactivity was $1-2 \%$ in solid areas of the tumor (Figure $4 \mathrm{C}$ ). With the histopathological and immunohistochemical findings, we signed out the case as "solid pseudopapillary neoplasm of the pancreas". The patient did not undergo any adjuvant therapy and has been doing well in the year after her operation.

\section{DISCUSSION}

SPN was first described by Gruber Frantz in 1959 and many cases or case series have been reported so far (27). It is usually seen in young women who present with abdominal pain, palpable abdominal mass or occasionally with mild or no clinical signs and symptoms $(2,5,6)$. Imaging studies consistently demonstrate a well-defined solid-cystic mass with variable degrees of hemorrhagic degeneration. Calcification is common. Characteristic fluid-debris levels and signal intensities seen with MRI indicate blood products (7). Our case presented with mild dull abdominal discomfort without any other clinical or laboratory abnormalities. MRI revealed a well-defined mass that was mainly cystic and only focally solid. The cystic
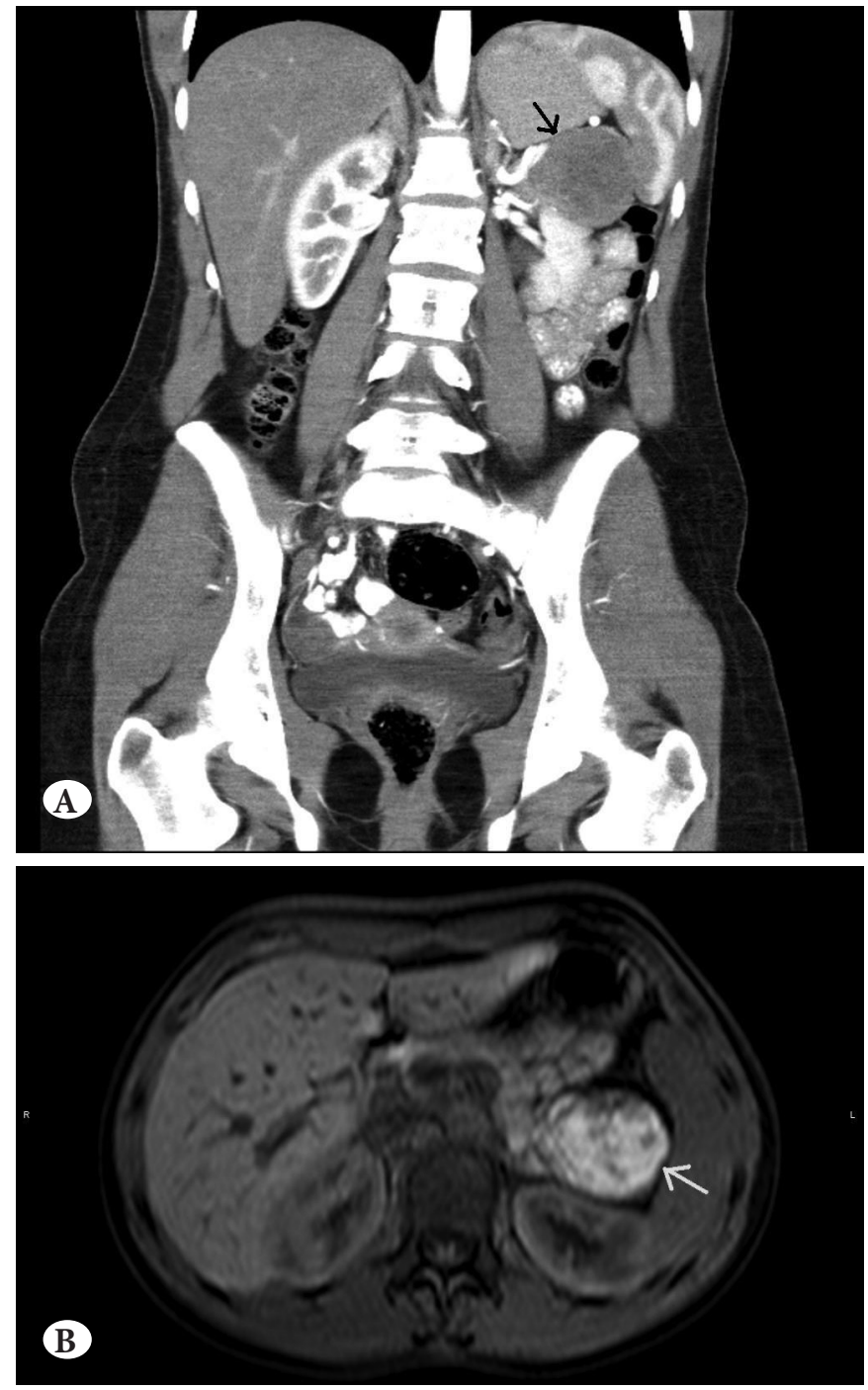

Figure 1: CT (A) \& MRI (B) revealed a well circumscribed, mainly cystic and partly solid mass (arrows) located in the tail of the pancreas.

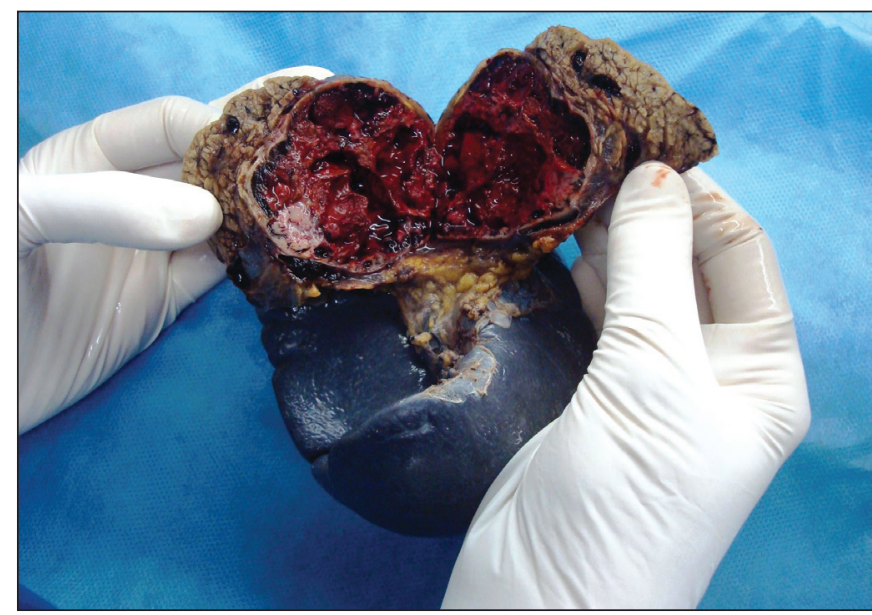

Figure 2: Grossly, the tumor was separated from the adjacent pancreatic tissue with a thin fibrous capsule. 

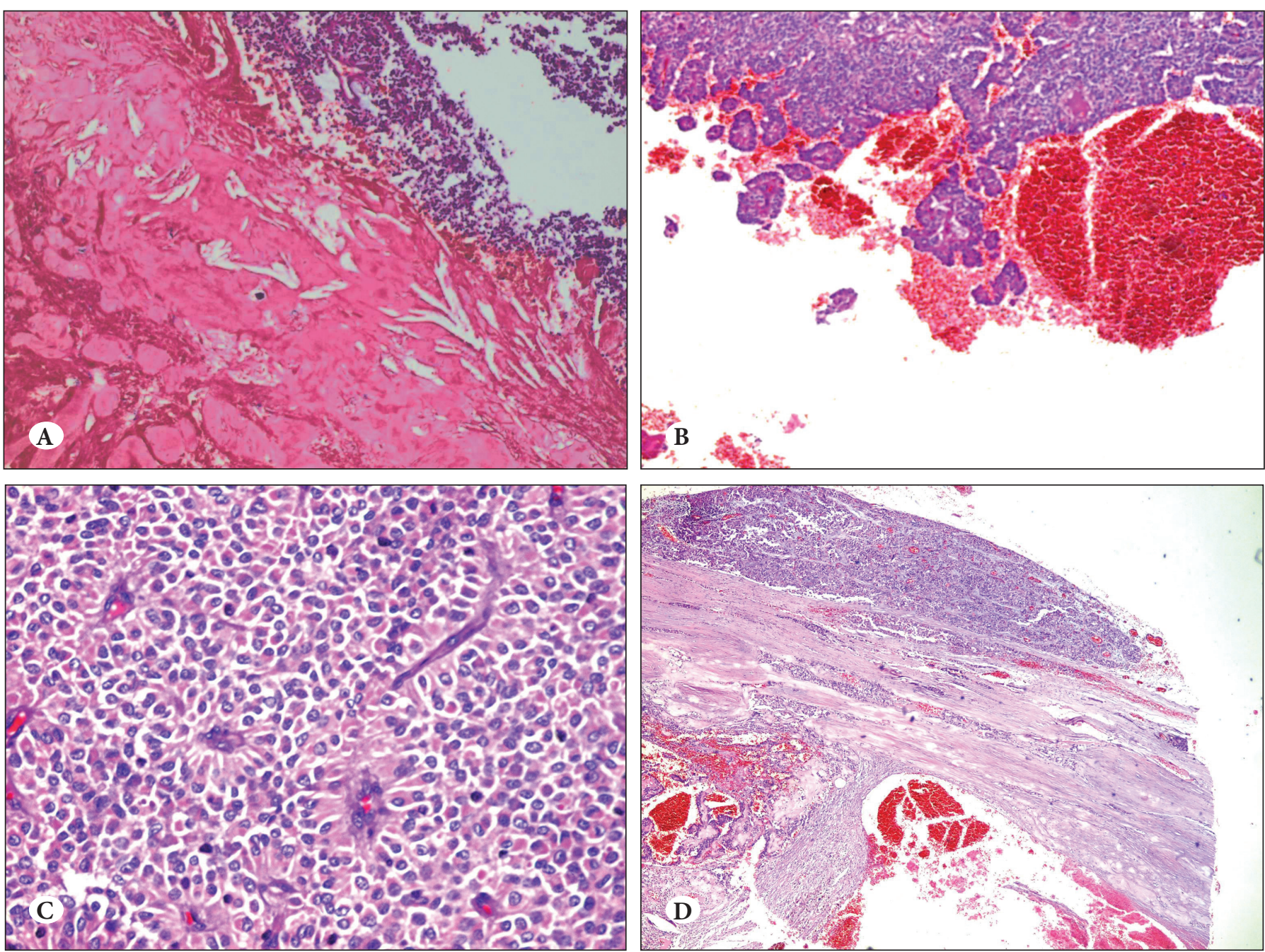

Figure 3: A) Cystic cavities within the tumor contained hemorrhagic material, cholesterol clefts and aggregated histiocytes (H\&E). B) The characteristic papillary and pseudopapillary structures lined by dyscohesive neoplastic cells (H\&E). C) The neoplastic cells with polygonal, uniform, centrally grooved nuclei and vacuolated and with eosinophilic large cytoplasm (H\&E). D) The tumor cells infiltrated the fibrous capsule in some areas (H\&E).

parts corresponding to the areas of hemorrhage showed hyperintensity on T1-weighted MRI sequences.

Grossly, the tumor is well circumscribed and may reach a huge size in some instances $(2,8)$. Invasion into the capsule, peritumoral tissues or adjacent pancreatic parenchyme (3) as well as distant metastasis to adjacent organs such as liver $(2,5)$, spleen (8) and regional lymph nodes (2) are reported in some series.

Immunohistochemically, SPN cells strongly and diffusely express vimentin, $\alpha-1$ antitrypsin, $\alpha-1$ antichymotrypsin (AACT), neuron specific enolase, $P R$ and $\beta$ form of ER $(1,7)$. CD10, CD56, CD 117, FLI-1, and also epithelial markers such as CK, AE1/AE3, CAM 5.2 can be focally positive (1). Chromogranine A, a specific endocrine marker, is typically negative or only very focally positive (1).
Abnormal nuclear localization of $\beta$ catenin gene results in nuclear staining $(1,3,6)$ and also this genetic abberation activates the Wnt-signaling pathway resulting in overexpression of cyclinD1, but not in overt malignancy of this tumor (9). In our case, we observed strong immunoreactivity for vimentin, $\beta$ catenin and weak staining for synaptophysin, PR and ER. Moderate expression of cyclinD1 was observed. There was no immunoreactivity for CD117, CD34, Chromogranine A, CK20 and CK7. Our immunohistochemistry results were consistent with the literature findings and supported our diagnosis of SPN.

The pathogenesis and the cell of origin of SPN remain unknown, since it lacks evidence of ductal, acinar or frank endocrine differentiation (1-5). The strong preponderance in young women and the common expression of PR 

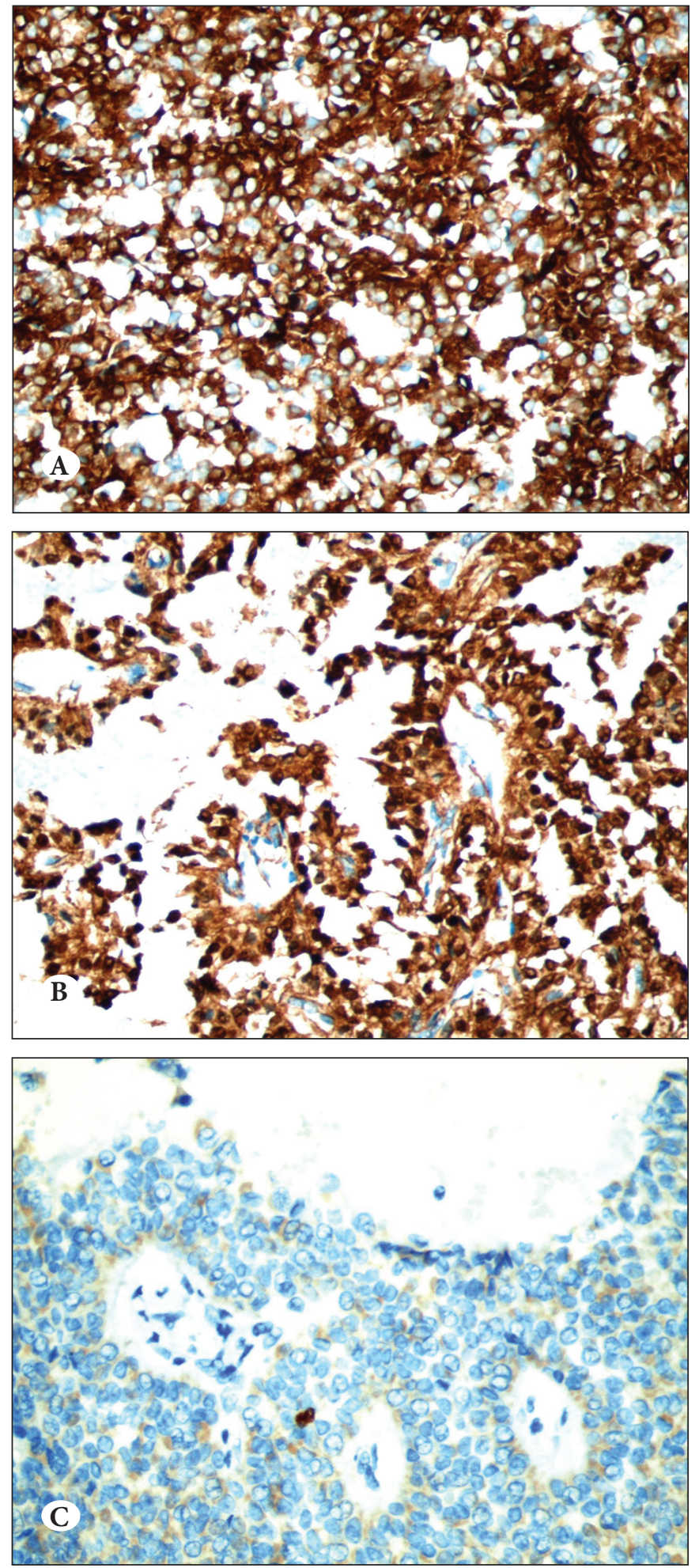

Figure 4: The tumor cells strongly stained with vimentin (A), $\beta$ catenin (B). Both nuclear and cytoplasmic staining for $\beta$ catenin was seen. Ki-67 labeling index was 1-2\% (C). suggests that during early embryogenesis, especially the left genital ridge cells come into contact with the pancreas and follow a different line of differentiation (10).

On the other hand, genetic changes involved in SPNs are different from the genetic changes involved in conventional ductal adenocarcinomas. Mutation in exon 3 of the $\beta$-catenin gene is a well-known genetic abberation in SPN (1).

Clinical behavior of SPN is still unclear. The long-term follow up of the patients showed that distant metastasis or invasion of the peritumoral tissues itself does not indicate aggressive clinical behavior of this tumor $(2,8)$. High-grade malignant transformation into undifferentiated carcinoma has been reported to be the only reliable predictor of clinical aggressiveness of this tumor till now (2). In our case, we noticed capsular invasion in focal areas and the tumor cells were very close to the adjacent pancreatic tissue. Our patient is well and free of any sign of disease on her second follow up one year after her operation.

In conclusion, SPT is a rare tumor of low malignant potential with uncertain origin. Capsular invasion or invasion of the tumor to the adjacent pancreas does not correlate with aggressive behavior. Radical resection of the lesion, where technically feasible, should be considered as the treatment of choice since it is safe and effective in controlling the disease.

\section{ACKNOWLEDGEMENT}

We would like to thank to Prof Dr Volkan Adsay of Emory University, Department of Pathology, Atlanta, USA for his diagnostic assistance.

\section{REFERENCES}

1. Basturk O, Coban I, Adsay NV. Pancreatic cysts: Pathologic classification, differential diagnosis, and clinical implications. Arch Pathol Lab Med. 2009;133:423-38.

2. Tang LH, Aydın H, Brennan MF, Klimstra DS. Clinically aggressive solid pseudopapillary tumors of the pancreas. A report of two cases with components of undifferentiated carcinoma and a comparative clinicopathologic analysis of 34 conventional cases. Am J Surg Pathol. 2005;29:512-9.

3. Chen S, Zou S, Dai Q, Huang P, Cai W, Li H. The clinicopathological and immunohistochemical analysis of solid-pseudopapillary tumor of the pancreas: Report of 9 cases. J Nanjing Med Univ. 2007;21:398-401.

4. Aydiner F, Erinanc H, Savas B, Erden E, Karayalcin K. Solid pseudopapillary tumor of the pancreas: Emphasis on differential diagnosis from aggressive tumors of the pancreas. Turk J Gastroenterol. 2006;17:219-22. 
5. Yang F, Jin C, Long J, Yu XJ, Xu J, Di Y, Li J, Fu de L, Ni QX. Solid pseudopapillary tumor of the pancreas: A case series of 26 consecutive patients. Am J Surg. 2009;198:210-5.

6. Yu PF, Hu ZH, Wang XB, Guo JM, Cheng XD, Zhang YL, Xu Q. Solid pseudopapillary tumor of the pancreas: A review of 553 cases in Chinese literature. World J Gastroenterol. 2010;16: 1209-14.

7. Buetow PC, Buck JL, Pantongrag-Brown L, Beck KG, Ros PR, Adair CF. Solid and papillary epithelial neoplasm of the pancreas: Imaging-pathologic correlation on 56 cases. Radiology. 1996; 199:707-11.
8. Petrakis I, Vrachassotakis N, Kogerakis N, Hatzidakis A, Zoras O, Chalkiadakis G. Solid pseudopapillary neoplasm of the pancreas: Report of a case after a 10-year follow-up and review of the literature. Pancreatology. 2001;1:123-8.

9. Tiemann K, Heitling U, Kosmahl M, Klöppel G. Solid pseudopapillary neoplasms of the pancreas show an interruption of the Wnt-signaling pathway and express gene products of 11q. Mod Pathol. 2007;20:955-60.

10. Klimstra DS, Wenig BM, Heffess CS. Solid-pseudopapillary tumor of the pancreas: A typical cystic tumor of low malignant potential. Semin Diagn Pathol. 2000;17:66-80. 